\title{
International Commodity Price Shocks, \\ Democracy, and External Debt
}

Rabah Arezki and Markus Brückner 


\title{
IMF Working Paper
}

IMF Institute

\section{International Commodity Price Shocks, Democracy, and External Debt Prepared by Rabah Arezki and Markus Brückner ${ }^{1}$}

Authorized for distribution by Marc Quintyn

0 DFK 2010

\begin{abstract}
This Working Paper should not be reported as representing the views of the IMF. The views expressed herein are those of the author and should not be attributed to the IMF, its Executive Board, or its management. Working Papers describe research in progress by the author(s) and are published to elicit comments and to further debate.

We examine the effects that international commodity price shocks have on external debt using panel data for a world sample of 93 countries spanning the period 1970-2007. Our main finding is that positive commodity price shocks lead to a significant reduction in the level of external debt in democracies, but to no significant reduction in the level of external debt in autocracies. To explain this result, we show that positive commodity price shocks lead to a statistically significant and quantitatively large increase in total government expenditures in autocracies. In democracies on the other hand government expenditures did not increase significantly. We also document that following positive windfalls from international commodity price shocks the risk of default on external debt decreased in democracies, but increased significantly in autocracies.
\end{abstract}

JEL Classification Numbers:C33, D73, D74, D72, H21

Keywords: Commodity Price Shocks; Debt Policy; Political Institutions

Author's E-Mail Address:rarezki@imf.org ; markus.bruckner@upf.edu

1 International Monetary Fund (Arezki) and Universitat Pompeu Fabra (Bruckner). Contact e-mail: rarezki@imf.org; markus.bruckner@upf.edu. We thank Ning Fu for excellent research assistance, Bertrand Candelon, Gian Maria Milesi-Ferretti, Enrica Degatriache, Thorvaldur Gylfason and Marc Quintyn for helpful comments and Ali Alichi for providing us with his dataset on external debt default. The views in this paper are those of the author(s) alone and do not necessarily represent those of the IMF or IMF policy. All remaining errors are our own. 


\section{Contents}

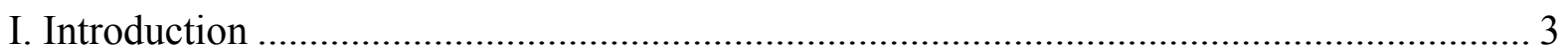

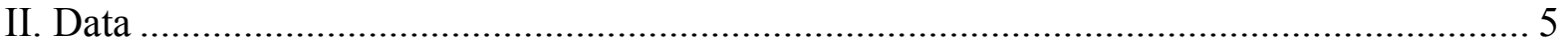

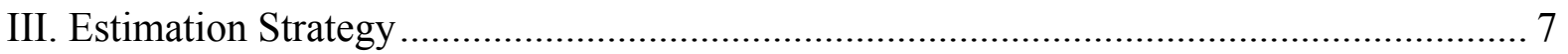

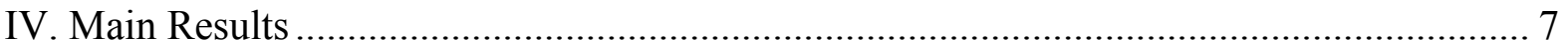

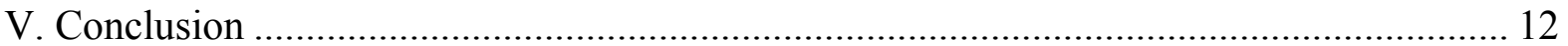

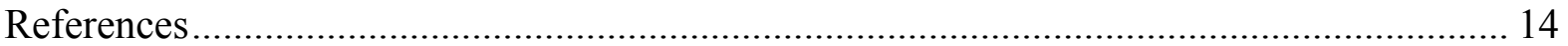

Table 1. Commodity Price Shocks and External Debt ............................................. 16

Table 2. Commodity Price Shocks, Democracy, and External Debt ............................... 17

Table 3. Commodity Price Shocks, Executive Constraints, Political Competition, and

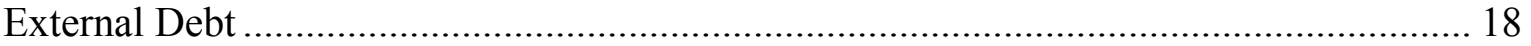

Table 4. Commodity Price Shocks, Political Institutions, and Government Expenditures 19

Table 5. Commodity Price Shocks, Political Institutions, and the Rule of Law............... 20

Table 6. Commodity Price Shocks, Political Institutions, and Economic Growth ............. 21

Table 7. Commodity Price Shocks, Political Institutions, and the Risk of Default on

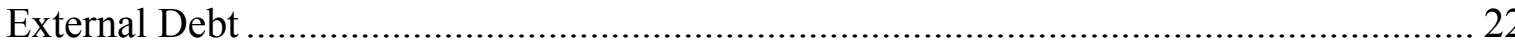




\section{INTRODUCTION}

Developing and emerging market economies are often faced with large international commodity price shocks that pose a number of serious challenges to their macroeconomic stability. ${ }^{2}$ We examine in this paper empirically how these countries use external borrowing to shield themselves against these shocks. Most recently, the concern that Dubai may default on the large external debt -- that it had accumulated over the past years when oil prices were booming -- has rekindled interest among policy makers and private investors in how international commodity price shocks are linked to external debt. We rigorously examine in this paper the link between international commodity price shocks and external debt using panel data for a world sample of over 93 countries during the period 1970-2007. We apply panel data techniques that account for both unobservable cross-country heterogeneity and common year shocks and identify in our empirical analysis the effects that international commodity price shocks have on external debt exclusively from the within-country variation of the data.

Our main finding is that increases in international commodity prices for exported commodity goods are associated with a significant reduction in external debt in democracies. In autocracies on the other hand, windfalls from international commodity prices did not lead to a significant reduction in external debt. While external debt therefore moved countercyclically with international commodity price shocks in democracies, there was no systematic relationship between international commodity price shocks and external debt in autocracies.

To explain the dichotomous response of external debt to international commodity price shocks we examine the response of government spending. It is well known that higher international commodity prices are associated in developing and emerging market countries with higher revenues that accrue to the government sector. What is not so well known however is whether governments in these countries systematically use the additional revenues to increase primarily total government expenditures, or reduce the level of debt. We find that in autocracies, windfalls from international commodity prices lead to a statistically

2 For example, international commodity price shocks may lead to a misalignment of the real exchange rate and a depletion of foreign reserves. For empirical analyses of the macroeconomic effects that international commodity price shocks have on economic growth see, for example, Deaton and Miller (1995), Collier and Goderis (2007), Raddatz (2007), or Bruckner and Ciccone (2010). 
significant and quantitatively large increase in government spending. In democracies on the other hand, the response in government spending to windfalls from international commodity prices is quantitatively small and statistically not significant. Hence, an examination of movements in government spending shows that commodity price shocks were associated with a significant procyclicality of government expenditures to international commodity price shocks in autocracies, while in democracies government expenditures were acyclical. At least in part, this significant increase in government spending in autocracies may explain why external debt was not significantly reduced in these countries: additional revenues accruing from international commodity price windfalls were directly spent by autocratic governments, with little to no savings left from which to finance a reduction in external debt. We also document that while in democracies international commodity price windfalls were associated with a significant improvement in the rule of law and real per capita GDP, in autocracies the rule of law did not improve significantly and neither did real per capita GDP despite the significant increase in total government expenditures.

Our paper is most closely related to the political economy literature on debt policy. Two key predictions from this literature are that more political uncertainty leads to a higher level of external debt, and that excessive corruption introduces procyclicality in government spending to revenue windfalls (Alesina and Tabellini, 1989; Alesina et al., 2008). To the extent that the severity of political uncertainty and corruption is higher in autocracies, the empirical results of our paper resonate these key predictions from the theoretical political economy literature on debt policy.

Our paper also contributes to a richer understanding of the link between political institutions and policy outcomes (see for example Persson, 2002). In their seminal contribution to the growth and institutions literature, Acemoglu et al. $(2001,2002)$ have shown that political institutions are key determinants for long-run economic development. Our present empirical analysis sheds novel insights on a specific, but nevertheless potentially important channel through which political institutions place developing and emerging market economies on different development paths: the accumulation of external debt that is due to plausibly exogenous international commodity price shocks. Indeed, the debt overhang literature has argued for a long time that high external debt levels have adverse effects on real per capita GDP growth (see for example Krugman, 1989; or Sachs, 1990). The main concern is that high external debt levels effectively act as a tax on future investment projects, and thus constrain the financing of these projects in the future. Our empirical results show that democracies use the additional revenues from international commodity price windfalls to reduce their external debt levels, but that autocracies systematically fail to do so. Instead, the later directly spend a large part of their additional revenues on government expenditures. Our empirical results therefore suggest that democracies use windfalls from international 
commodity price shocks more conservatively than autocracies, and thus effectively evade the future tax burden on investment that stems from an accumulation of external debt.

Finally, our paper contributes novel empirical insights on the voracity effect described in the theoretical models of Lane and Tornell (1998) and Tornell and Lane (1999) where revenue windfalls from positive terms-of-trade shocks are predicted to lead to a disproportionate increase in fiscal redistribution in countries with weak legal-political institutions. As stressed by the authors, from a theoretical point of view it is unclear whether a shift from autocracy to democracy ameliorates or exacerbates this voracity effect. What matters for the voracity effect is whether strong democratic institutions successfully constrain powerful groups from extracting transfers from the government budget.

Our empirical results suggest that this is indeed the case: democracies are on average more successful in constraining powerful groups from extracting transfers from the government budget in the wake of windfalls from international commodity price shocks than autocracies. In particular, when we focus specifically on the constraints placed on the political executive by the political institutions in place we find a significant positive effect of international commodity price shocks on government expenditures in countries with weak executive constraints, and an insignificant effect of international commodity price shocks on government expenditures in countries with strong executive constraints. Moreover, for countries with strong executive constraints positive international commodity price shocks had also a significant positive effect on real per capita GDP growth, while in countries with weak executive constraints international commodity price shocks did not affect GDP growth significantly. Hence, our empirical analysis provides evidence that the voracity effect was well at work in countries with weak political institutions, but that countries with strong political institutions were mostly shielded from it. Finally, and perhaps most interesting for policy makers and private investors we show that while windfalls from international commodity price shocks reduced the risk of default on external debt in democracies, this risk significantly increased in autocracies.

For the remainder our paper is organized as followed. Section 2 describes the data. Section 3 discusses the estimation strategy. Section 4 presents the main results. Section 5 concludes.

\section{DATA}

International Commodity Price Shocks. We constructed a country-specific international commodity price index that captures shocks to the international prices of exported commodities as: 


$$
\text { Com Pr iceShock }{ }_{i, t}=\sum_{c \in C} \theta_{i, c} \Delta \log \left(\text { Com }_{\operatorname{Pr}} \text { ice }_{c, t}\right)
$$

where ComPrice Cot $_{\text {is }}$ is the international price of commodity $c$ in year $t$, and $\theta_{i, c}$ is the average (time-invariant) value of exports of commodity $c$ in the GDP of country $i$. Annual international commodity price data are for the 1970-2007 period from UNCTAD Commodity Statistics, and data on the value of commodity exports is from the NBER-United Nations Trade Database. Because the time-series behavior of many international commodity prices is highly persistent, commodity price shocks are identified by the $(\log )$ change in the international commodity price. ${ }^{3}$

External Debt. Data on the total external debt stock are from the World Bank, Global Development Finance (2009). Total external debt is debt owed to nonresidents repayable in foreign currency, goods, or services. ${ }^{4}$ We focus on external debt because data on domestic public debt are not available for many countries, and are moreover difficult to compare across countries as countries with weak administrative capacity often consolidate their accounts at the central government level whereas countries with strong administrative capacity often consolidate their accounts at the general government level.

Democracy. Democracy is measured by the revised combined Polity score (Polity2) of the Polity IV database (Marshall and Jaggers, 2009). The Polity 2 score ranges from -10 to +10 , with higher values indicating more democratic institutions. Following Persson and Tabellini (2003, 2006) and the Polity IV project, we code countries as democracies (autocracies) if their Polity2 score is strictly positive (negative). We further classify countries as deep democracies if their Polity2 score is larger than 6; and as deep autocracies if their Polity2 score is smaller than -6 .

To examine also specifically the political competition and executive constraints channel, we use the polity sub-scores on constraints on the chief executive and political competition. According to the Polity IV project, constraints on the executive is a measure of the extent of

3 The commodities included in our index are: aluminum, beef, coffee, cocoa, copper, cotton, gold, iron, maize, oil, rice, rubber, sugar, tea, tobacco, wheat, and wood. In case there were multiple prices listed for the same commodity we used a simple average of all the relevant prices.

4 Total external debt is debt owed to nonresidents repayable in foreign currency, goods, or services. Total external debt is the sum of public, publicly guaranteed, and private nonguaranteed long-term debt, use of IMF credit, and short-term debt. Short-term debt includes all debt having an original maturity of one year or less and interest in arrears on long-term debt. 
institutionalized constraints on the decision making powers of chief executives and ranges from 1 to 7, with greater values indicating tighter constraints. Political competition measures the extent to which alternative preferences for policy and leadership can be pursued in the political arena. This indicator ranges from 1 to 10, with greater values denoting more competition.

\section{ESTIMATION STRATEGY}

To examine the effects that international commodity price shocks have on external debt and other key variables of interest, we estimate the following econometric model:

$$
\Delta \log \left(\text { ExternalDebt }_{i, t}=\alpha_{i}+\beta_{t}+\gamma\left(\text { Com PriceShock }_{i, t}\right)+u_{i, t}\right.
$$

where $\alpha_{i}$ are country fixed effects that capture time-invariant country-specific unobservables and $\beta_{t}$ are year fixed effects that capture common year shocks. $u_{i, t}$ is an error term that is clustered at the country level. As a baseline regression, we estimate the average marginal effect that commodity price shocks have on external debt in a world sample. We then split the sample into autocracies and democracies and estimate separately for these two groups the effects that commodity price shocks have on external debt (and other key variables of interest). To formally test whether the estimated coefficient on the international commodity price variable in the autocracy sample is significantly different from the estimated coefficient in the democracy sample we apply a generalized form of the Chow test that allows for arbitrary within-country serial correlation of the error term.

\section{Main Results}

Table 1 presents our estimates of the average marginal effect that commodity price shocks have on external debt in a world sample. The main finding from the distributed lag estimates is that positive $t-1$ international commodity price shocks lead to a significant reduction in external debt. Column (1) presents the pooled panel estimates that do not control for country or year fixed effects and this yields a significant negative $t$ - 1 effect of international commodity price shocks on external debt that is significant at the $1 \%$ level. In column (2) the country fixed effects are included in the regression which does not change the point estimates substantially. When controlling in addition to the country fixed effects for also the year fixed effects that capture global business cycle effects the effect of $t$ - 1 commodity price shocks on external debt becomes smaller in absolute size but remains negative and statistically significant at the 5\% level (column (3)). Quantitatively, the year and country fixed effects 
estimates imply that a positive international commodity price shock of size 1 standard deviation significantly decreased on average external debt by over 0.04 standard deviations. ${ }^{5}$

In column (4) we present panel fixed effects estimates that include on the right-hand side of the estimating equation commodity price shocks in period $t+1$. The motivation for including period $t+1$ commodity price shocks is to check whether external debt reacts to future, potentially anticipated changes in international commodity prices. We find that the point estimate on period $t+1$ commodity price shocks is not statistically significant. Quantitatively, the point estimate is also quite small. Hence, we do not find evidence of significant anticipatory effects. ${ }^{6}$ Moreover, the effect of period $t-1$ commodity price shocks on external debt remains negative and statistically significant at the $5 \%$ level. This continues to be also the case when controlling for country-years where the country was granted a relief of its external debt (see column (5)).

To take into account dynamics in the evolution of external debt, we show in columns (6) and (7) dynamic panel estimates that include on the right-hand side of the estimating equation the lagged level of external debt. Both the least squares and system-GMM estimates show that there is quite a bit of persistence in the dynamics of the external debt stock. The estimated convergence coefficient is -0.120 and implies a half life in shocks to the level of external debt of around 5.4 years. Most importantly, the dynamic panel data estimates confirm that there is a significant negative $t-1$ effect of international commodity price shocks on external debt. $^{7}$

In Table 2 we examine how democratic institutions affect the relationship between international commodity price shocks and debt accumulation by separating countries into

5 We have checked whether there is an asymmetry between positive and negative commodity price shocks by including in the regression an interaction dummy that captures differences in the marginal effect between negative and positive commodity price shocks. We found that this interaction variable on differences in the marginal effect between negative and positive shocks is statistically insignificant. We also checked for further non-linearities by including a quadratic term of international commodity price shocks, which also turned out to be insignificant.

6 We have also checked for the statistical significance of further leads in commodity price shocks and found that they were insignificant.

7 We have also checked whether price shocks of different commodities (i.e. minerals vs. agricultural commodities) have different effects on external debt. We did not find a significantly different impact of these two categories. 
four different categories that reflect differences in countries' democratic institutions based on the Polity2 score. Our main finding is that the significant negative effect of international commodity price shocks on external debt is particularly large and statistically significant for democracies. For autocracies we find that the estimated relationship is statistically insignificant and quantitatively the point estimates are very small. The point estimate in column (1) implies that for countries with deep democratic institutions (i.e. Polity 2 scores larger than 6) a positive international commodity price shock of size 1 standard deviation leads to a significant reduction in external debt by over 0.24 standard deviations. This is quite a large effect. Moreover, in column (2) where we include also those countries that have strictly positive Polity2 scores we still obtain a significant negative relationship between international commodity price shocks and external debt accumulation. However, the estimated coefficient on the international commodity price shock variable is quantitatively much smaller. And, in columns (3) and (4) where we focus on autocracies the estimated relationship is statistically insignificant. Moreover, quantitatively the effect of international commodity price shocks on debt accumulation is essentially zero for these countries. The Chow test rejects the hypothesis that the structural coefficient in the autocracy sample is the same as the structural coefficient in the democracy sample. Hence, the Chow test confirms that also in the statistical sense the effect of international commodity price shocks on external debt in democracies is significantly different from the effect in autocracies. ${ }^{8}$

Table 3 shows that we obtain similar results when running separate regressions for countries with strong executive constraints and strong political competition on the one hand, and countries with weak executive constraints and weak political competition on the other hand. In particular, in countries with strong executive constraints and a high degree of political competition we find that windfalls from international commodity price shocks lead to a statistically significant and a quantitatively large reduction in external debt (see columns (1) and (3)). In countries with weak executive constraints and weak political competition windfalls from international commodity price shocks do not lead on average to a significant reduction in external debt (see columns (2) and (4)).

A possible explanation for why windfalls from international commodity price shocks lead to a significant reduction in external debt in countries with strong democratic institutions, but not in countries with weak democratic institutions is that strong democratic institutions

\footnotetext{
${ }^{8}$ We have also examined the case of running an interaction model where we control for an additional interaction effect between international commodity price shocks and countries' per capita GDP level. We continue to find in this case that there is only a significant negative effect of international commodity price shocks on external debt in democracies, while in autocracies the effect is insignificant.
} 
effectively constrain political leaders in spending additional revenues on wasteful activities. In Table 4, we provide supportive empirical evidence for this explanation by documenting that in autocracies and countries that have weak executive constraints and slack political competition, positive commodity price shocks lead to a highly significant and quantitatively large increase in total government expenditures. ${ }^{9}$ On the other hand, in democracies and countries with strong executive constraints and strong political competition positive international commodity price shocks did not lead to a significant increase in total government expenditures. Table 4 therefore shows that while in autocracies commodity price windfalls were used to increase government spending, this did not happen systematically so in democracies.

In Table 5 we explore a further channel through which dichotomy in the response of external debt to international commodity price shocks may arise: the rule of law, which is a safeguard against arbitrary governance and abuse by those who are in power. Interestingly, we find that in democracies the rule of law significantly increased in the presence of windfalls from international commodity price shocks. On the other hand, in autocracies the rule of law deteriorated, or at best did not change significantly. Note that in autocracies the relationship is quite imprecisely estimated so that we cannot reject that the effect is significantly different from zero. Nevertheless, we can reject at quite a high level of confidence that the structural relationship between windfalls from international commodity price shocks and the rule of law in democracies is the same as in democracies.

Table 6 documents that positive international commodity price shocks were associated with higher real per capita GDP growth in democracies and countries with strong executive constraints and high levels of political competition. In autocracies and countries with weak executive constraints and low levels of political competition -- where a large part of the commodity price windfalls were directly spent by the government (see Table 4) -- there was no significant effect on real per capita GDP growth however. This suggests that while commodity price windfalls were conservatively administered in democracies, in autocracies the high government spending did not even lead to a significant increase in output. All in all, our results therefore point to positive commodity price shocks leading to a significant reduction in external debt in democracies because the democratic institutions placed

9 Data on total government expenditures are from Heston et al. (2009). 
sufficient constraints on politicians, prohibiting them from spending the windfalls on socially sub-optimal activities. ${ }^{10}$

In Table 7 we report the effect that international commodity price shocks have on the risk of the country defaulting on its external debt. ${ }^{11}$ We use the conditional logit fixed effects estimator to take into account the nonlinear structure of our dependent variable and that standard nonlinear probability models (such as the logit or probit model) produce biased estimates of the slope coefficients when country fixed effects are used. ${ }^{12}$ Consistent with our previous findings, the nonlinear probability estimates show that the structural relationship between international commodity price shocks and the risk of default in democracies is significantly different from the structural relationship in autocracies. Moreover, in autocracies we find that the risk of default significantly increases following windfalls from positive international commodity price shocks. ${ }^{13}$ For the democracy sample, we also find that the estimated effect that positive international commodity price shocks have on the risk of debt default is negative. Statistically, we are unable to reject that in the democracy sample the effect of international commodity price shocks on the risk of debt default is different from zero. However, this is due to a much larger standard error on the point estimates in the democracy sample, which follows from the democracy sample being quite a bit smaller than the autocracy sample. Moreover, quantitatively the size of the point estimates is actually larger (in absolute terms) in the democracy sample than in the autocracy sample.

10 Obviously, we recognize that government expenditures could have potentially high social returns in autocracies. However, they may be rendered inefficient because of the lack of transparency and corruption that is associated with government spending in many autocratic regimes.

11 The data on external debt default are from Beers and Chambers (2003).

12 This is due to the incidental parameter problem (see for example Wooldridge, 2002). The conditional logit fixed effects model does not suffer from this bias because slope estimates are computed from using maximum likelihood estimation of the density function that is conditional on the country fixed effects. Note that the point estimates reported in Table 7 do not represent marginal effects because this would require knowledge of the distribution of the country fixed effects.

13 This finding matches with the graphical and mostly informal evidence presented in Manzano and Rigobon (2001) that rising commodity prices in the 70s triggered a debt overhang in many resource rich countries. 


\section{CONCLUSION}

We have examined in this paper the relationship between international commodity price shocks and external debt using rigorous panel data techniques that allow to identify the effects that international commodity price shocks have on external debt exclusively from the within-country variation of the data. Our main finding is that external debt moves countercyclically with international commodity price shocks, but that this relationship is not unconditional on the political institutions that are in place in the debtor country. In particular, we find that while external debt moved highly countercyclically in democracies it moved acyclically in autocracies. We made an attempt to explain this finding by documenting that autocracies mostly spent the additional revenues accruing from international commodity price shocks by increasing government expenditures, while democracies kept a large part of the windfalls to reduce their external debt. Our empirical results therefore highlight the role of political institutions in shaping external debt policy. We would also like to point out that the average level of external debt in autocracies is not significantly different in our sample from the average level of external debt in democracies. Hence, it is not the case that autocracies are less able to finance themselves on the international capital market than democracies.

We did not build in our paper a theoretical model, but a plausible and intuitive way to make sense of our empirical results is to focus on the constraints that democratic institutions place on political leaders. A key feature of democracies (relative to autocracies) is that political leaders are more easily held accountable to the public and therefore respond more readily to the demands of the majority of citizens. When politicians directly spend the additional revenue windfalls on consumption and investment goods, wages, or transfers there is an inherent risk that this spending is socially sub-optimal because of the lack of allocative and technical efficiency. In particular, the way that government expenditures are administered may not be very transparent. Reducing external debt on the other hand is a clear and transparent strategy that will be associated with a lower tax on future investment projects. Spending revenue windfalls on reducing external debt rather than increasing total government expenditures should therefore be the preferred strategy by the majority of citizens, and hence by the median voter, if there is a severe risk that revenue windfalls from international commodity price shocks are sub-optimally administered by the government. Because autocratic leaders are much less accountable to the citizens, they spend a large part of the windfalls on government expenditures and by doing so create discretionary space for abusing public office for private purposes.

One important policy question that we have not touched on in this paper, and which may be worthwhile exploring empirically in the future as the data become available, is whether fiscal rules could help reduce the high procyclicality of government spending to international 
commodity price shocks in autocracies. Studies that have looked at this issue for the US have found rather mixed evidence. Some studies find that fiscal rules do effectively reduce the cyclicality of macroeconomic variables (among these are for example Fatas and Mihov, 2006), while others have failed to find a significant relationship (see for example Canova and Pappa, 2006). The key issue of course is whether fiscal rules effectively constrain politicians in their policy decisions. If politicians find ways to work around the fiscal rules, through for example creative accounting (e.g. Milesi-Ferretti, 2004), then fiscal rules will not be very effective. It therefore remains to be answered empirically whether fiscal rules can help reduce in autocracies the high procyclicality of government spending to international commodity price shocks. 


\section{REFERENCES}

Acemoglu, D., S. Johnson, and J. Robinson (2001). "The Colonial Origins of Comparative Development: An Empirical Investigation." American Economic Review 91: 13691401.

, (2002). "Reversal of Fortune: Geography and Institutions in the Making of the Modern World Income Distribution." Quarterly Journal of Economics 117: 12311294.

Alesina, A. and G. Tabellini (1989). "External Debt, Capital Flight, and Political Risk." Journal of International Economics 27: 199-220.

Alesina, A., F. Campante, and G. Tabellini (2008). "Why is Fiscal Policy Often Procyclical?" Journal of the European Economic Association 6: 1006-1036.

Beers, D. T., and J. Chambers (2003). "Sovereign Defaults: Heading Lower into 2004." Standard and Poors, New York.

Bruckner, M. and A. Ciccone (2010). "International Commodity Price Shocks, Growth, and the Outbreak of Civil War in Sub-Saharan Africa." forthcoming Economic Journal.

Canova, F. and E. Pappa (2006). "The Elusive Costs and Immaterial Gains of Fiscal Constraints." Journal of Public Economics 90: 1391-1414.

Collier P., and B. Goderis (2007). "Commodity Prices, Growth, and the Natural Resource Curse: Reconciling a Conundrum". CSAE Working Paper Series No. 276.

Deaton, A. and R. Miller (1995). International Commodity Prices, Macroeconomic Performance, and Politics in Sub-Saharan Africa. Princeton Studies in International Finance.

Fatas, A. and I. Mihov (2006). "The Macroeconomic Effects of Fiscal Rules in the US States." Journal of Public Economics 90: 101-117.

Heston, A., R. Summers and B. Aten (2009). "Penn World Table Version 6.3", Center for International Comparisons of Production, Income and Prices at the University of Pennsylvania, August 2009. 
Krugman, P. (1988). "Financing vs. Forgiving a Debt Overhang," Journal of Development Economics 29: 253-268.

Lane, P. and A. Tornell (1996). Power, Growth, and the Voracity Effect." Journal of Economic Growth 1: 213-241

Milesi-Ferretti, G. (2004). "Good, Bad or Ugly? On the Effects of Fiscal Rules with Creative Accounting." Journal of Public Economics 88: 377-394.

Manzano, O., and R. Rigobon (2001). "Resource Curse or Debt Overhang?" NBER Working Paper No. 8390.

Persson, T. (2002). "Do Political Institutions Shape Economic Policy." Econometrica 70: 883-905.

Persson, T. and G. Tabellini (2003). The Economic Effects of Constitutions. MIT Press, Cambridge.

Persson, T. and G. Tabellini (2006). "Democracy and Development. The Devil in Detail." American Economic Review Papers and Proceedings 96 (2): 319-324.

Raddatz, C. (2007). "Are External Shocks Responsible for the Instability of Output in LowIncome Countries?" Journal of Development Economics 84:155-187.

Tornell, A. and P. Lane (1999). "The Voracity Effect." American Economic Review 89: 2246.

Wooldridge, J. (2002). Econometric Analysis of Cross Section and Panel Data. Cambridge, Mass.: MIT Press.

World Bank (2009). World Development Indicators (Washington D.C., World Bank). 
Table 1. Commodity Price Shocks and External Debt

\begin{tabular}{|c|c|c|c|c|c|c|c|}
\hline \multicolumn{8}{|c|}{$\Delta$ External Debt } \\
\hline & (1) & (2) & (3) & (4) & (5) & (6) & (7) \\
\hline & LS & LS & LS & LS & LS & LS & SYS-GMM \\
\hline ComPrice & -0.524 & -0.503 & -0.182 & -0.160 & -0.203 & -0.108 & -0.227 \\
\hline Shock, $\mathrm{t}$ & $(-1.03)$ & $(-0.94)$ & $(-0.38)$ & $(-0.34)$ & $(-0.43)$ & $(-0.21)$ & $(-0.40)$ \\
\hline ComPrice & $-1.387 * * *$ & $-1.377 * * *$ & $-0.844 * *$ & $-0.905^{* *}$ & $-0.856^{* *}$ & $-0.980^{* *}$ & $-0.671^{*}$ \\
\hline Shock, t-1 & $(-3.69)$ & $(-3.62)$ & $(-1.97)$ & $(-2.06)$ & $(-1.97)$ & $(-2.48)$ & $(-1.79)$ \\
\hline ComPrice & 0.020 & 0.070 & -0.291 & -0.306 & -0.294 & -0.173 & -0.573 \\
\hline Shock, t-2 & $(0.07)$ & $(0.24)$ & $(-0.89)$ & $(-0.90)$ & $(-0.90)$ & $(-0.40)$ & $(-1.23)$ \\
\hline ComPrice & & & & -0.167 & & & \\
\hline Shock, $\mathrm{t}+1$ & & & & $(-0.37)$ & & & \\
\hline \multirow[t]{2}{*}{ Debt Relief } & & & & & $-0.165^{* * *}$ & & \\
\hline & & & & & $(-2.78)$ & & \\
\hline \multirow[t]{2}{*}{ Debt, t-1 } & & & & & & $-0.161 * * *$ & $-0.120 * * *$ \\
\hline & & & & & & $(-5.97)$ & $(-3.54)$ \\
\hline Country Fe & No & Yes & Yes & Yes & Yes & Yes & Yes \\
\hline Year Fe & No & No & Yes & Yes & Yes & Yes & Yes \\
\hline Observations & 2676 & 2676 & 2676 & 2583 & 2676 & 2676 & 2676 \\
\hline
\end{tabular}

Note: The dependent variable is the log-change of external debt. The method of estimation in columns (1)-(6) is least squares; column (7) system-GMM (Blundell and Bond, 1998). The t-values shown in parentheses below the point estimates are based on Huber robust standard errors that are clustered at the country level. *Significantly different from zero at 90 percent confidence, ** 95 percent confidence, *** 99 percent confidence. 
Table 2. Commodity Price Shocks, Democracy, and External Debt

\begin{tabular}{|c|c|c|c|c|}
\hline & \multicolumn{3}{|c|}{$\underline{\Delta \text { External Debt }}$} & \multirow{3}{*}{$\begin{array}{c}\text { Deep Autocracy } \\
\text { (Polity } 2<-6)\end{array}$} \\
\hline & Deep Democracy & Democracy & Autocracy & \\
\hline & (Polity2 >6) & (Polity2 $>0$ ) & (Polity $<=0$ ) & \\
\hline & (1) & (2) & (3) & (4) \\
\hline \multirow{3}{*}{ ComPrice Shock, t-1 } & LS & LS & LS & LS \\
\hline & $-6.103 * * *$ & $-1.676^{* *}$ & -0.098 & -0.024 \\
\hline & $(-2.64)$ & $(-2.16)$ & $(-0.18)$ & $(-0.03)$ \\
\hline Chow Test: Coefficient is & . & {$[0.017]$} & {$[0.007]$} & {$[0.008]$} \\
\hline same as in Column (1) & & & & \\
\hline Country Fe & Yes & Yes & Yes & Yes \\
\hline Year Fe & Yes & Yes & Yes & Yes \\
\hline Observations & 409 & 1221 & 1445 & 357 \\
\hline
\end{tabular}

Note: The dependent variable is the log-change of external debt. The method of estimation is least squares; the t-values (shown in parentheses) below the point estimates are based on Huber robust standard errors that are clustered at the country level. P-values are reported [in square brackets] on the null hypothesis of the Chow test that the point estimate on the ComPrice Shock, $t-1$ variable is the same as in column (1). *Significantly different from zero at 90 percent confidence, $* * 95$ percent confidence, $* * * 99$ percent confidence. 
Table 3. Commodity Price Shocks, Executive Constraints, Political Competition, and External Debt

\author{
$\underline{\Delta \text { External Debt }}$
}

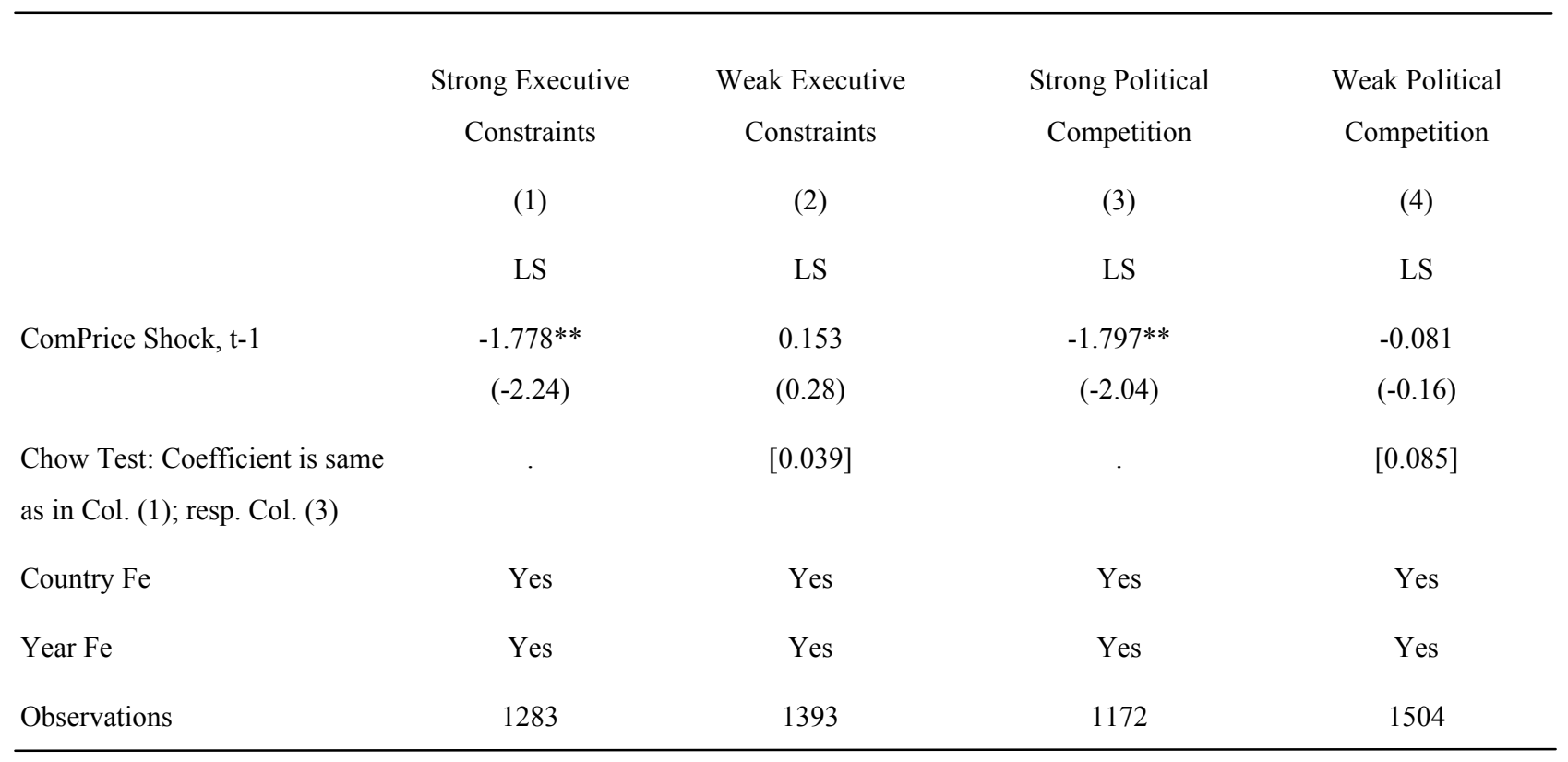

Note: The dependent variable is the log-change of external debt. The method of estimation is least squares; t-values (shown in parentheses) below the point estimates are based on Huber robust standard errors that are clustered at the country level. P-values are reported [in square brackets] on the null hypothesis of the Chow test that the point estimate in column (1) (respectively, column (3)), on the ComPrice Shock, $t$ 1 variable is the same as in column (2) (respectively, column (4)). Strong (weak) executive constraints refers to countries that have according to the Polity IV database an above (below) median sample score of executive constraints; strong (weak) political competition refers to countries that have according to the Polity IV database an above (below) median sample score of political competition. *Significantly different from zero at 90 percent confidence, ** 95 percent confidence, *** 99 percent confidence. 
Table 4. Commodity Price Shocks, Political Institutions, and Government Expenditures

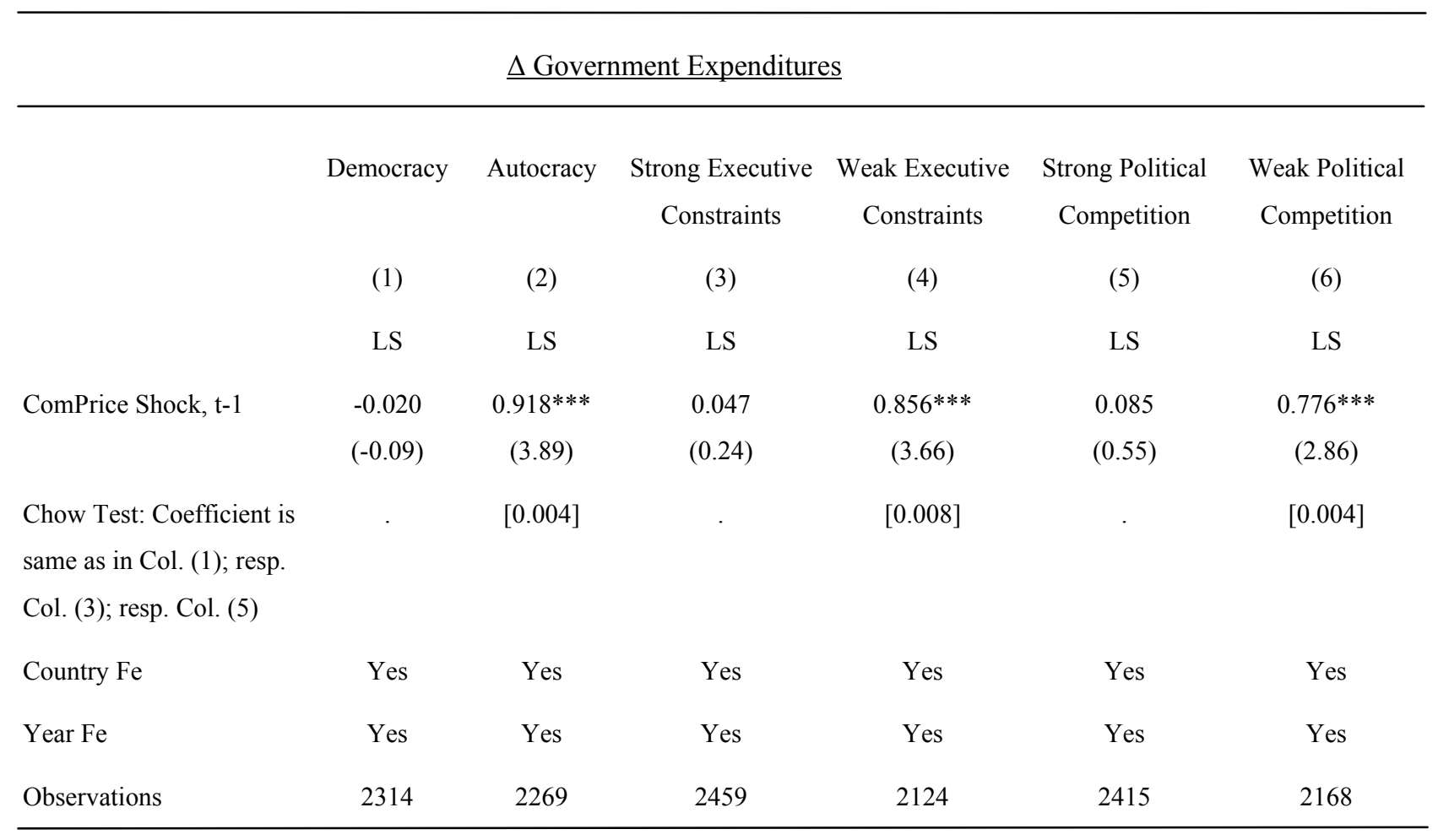

Note: The dependent variable is the log-change of total government expenditures. The method of estimation is least squares; $t$-values (shown in parentheses) below the point estimates are based on Huber robust standard errors that are clustered at the country level. P-values are reported [in square brackets] on the null hypothesis of the Chow test that the point estimate in column (1) (respectively column (3) and (5)), on the ComPrice Shock, $t$ - 1 variable is the same as in column (2) (respectively, column (4) and (6)). Democracy (Autocracy) refers to countries that according to the Polity IV database have a strictly positive (negative) Polity2 score. Strong (weak) executive constraints refers to countries that have according to the Polity IV database an above (below) median sample score of executive constraints; strong (weak) political competition refers to countries that have according to the Polity IV database an above (below) median sample score of political competition. *Significantly different from zero at 90 percent confidence, $* * 95$ percent confidence, $* * * 99$ percent confidence. 
Table 5. Commodity Price Shocks, Political Institutions, and the Rule of Law

\begin{tabular}{|c|c|c|c|c|c|c|}
\hline \multicolumn{7}{|c|}{$\Delta$ Rule of Law } \\
\hline & Democracy & Autocracy & $\begin{array}{c}\text { Strong Executive } \\
\text { Constraints }\end{array}$ & $\begin{array}{c}\text { Weak Executive } \\
\text { Constraints }\end{array}$ & $\begin{array}{c}\text { Strong Political } \\
\text { Competition }\end{array}$ & $\begin{array}{c}\text { Weak Political } \\
\text { Competition }\end{array}$ \\
\hline & (1) & (2) & (3) & (4) & (5) & (6) \\
\hline & LS & LS & LS & LS & LS & LS \\
\hline ComPrice Shock, t-1 & $\begin{array}{c}3.725^{* *} \\
(2.38)\end{array}$ & $\begin{array}{l}-0.401 \\
(-0.46)\end{array}$ & $\begin{array}{c}3.836^{* *} \\
(2.43)\end{array}$ & $\begin{array}{l}-0.572 \\
(-0.67)\end{array}$ & $\begin{array}{l}4.321 * * \\
(2.44)\end{array}$ & $\begin{array}{l}-0.494 \\
(-0.65)\end{array}$ \\
\hline $\begin{array}{l}\text { Chow Test: Coefficient is } \\
\text { same as in Col. (1); resp. } \\
\text { Col. (3); resp. Col. (5) }\end{array}$ & & {$[0.020]$} & & {$[0.013]$} & & {$[0.011]$} \\
\hline Country Fe & Yes & Yes & Yes & Yes & Yes & Yes \\
\hline Year Fe & Yes & Yes & Yes & Yes & Yes & Yes \\
\hline Observations & 1256 & 1214 & 1334 & 1136 & 1214 & 1256 \\
\hline
\end{tabular}

Note: The dependent variable is the change in the ICRG rule of law variable. The method of estimation is least squares; t-values (shown in parentheses) below the point estimates are based on Huber robust standard errors that are clustered at the country level. P-values are reported [in square brackets] on the null hypothesis of the Chow test that the point estimate in column (1) (respectively, column (3)) and (5)), on the ComPrice Shock, $t-1$ variable is the same as in column (2) (respectively, column (4) and (6)). Democracy (Autocracy) refers to countries that according to the Polity IV database have a strictly positive (negative) Polity2 score. Strong (weak) executive constraints refers to countries that have according to the Polity IV database an above (below) median sample score of executive constraints; strong (weak) political competition refers to countries that have according to the Polity IV database an above (below) median sample score of political competition. *Significantly different from zero at 90 percent confidence, $* * 95$ percent confidence, $* * * 99$ percent confidence. 


\section{Table 6. Commodity Price Shocks, Political Institutions, and Economic Growth}

\begin{tabular}{|c|c|c|c|c|c|c|}
\hline & & & $\underline{\Delta \mathrm{GDP}}$ & & & \\
\hline & Democracy & Autocracy & $\begin{array}{c}\text { Strong Executive } \\
\text { Constraints }\end{array}$ & $\begin{array}{c}\text { Weak Executive } \\
\text { Constraints }\end{array}$ & $\begin{array}{c}\text { Strong Political } \\
\text { Competition }\end{array}$ & $\begin{array}{c}\text { Weak Political } \\
\text { Competition }\end{array}$ \\
\hline & (1) & (2) & (3) & (4) & (5) & (6) \\
\hline & LS & LS & LS & LS & LS & LS \\
\hline ComPrice Shock, t-1 & $\begin{array}{l}0.269^{*} \\
(1.83)\end{array}$ & $\begin{array}{l}-0.317 \\
(-1.23)\end{array}$ & $\begin{array}{l}0.275^{*} \\
(1.84)\end{array}$ & $\begin{array}{l}-0.329 \\
(-1.28)\end{array}$ & $\begin{array}{c}0.300^{* *} \\
(2.19)\end{array}$ & $\begin{array}{l}-0.341 \\
(-1.32)\end{array}$ \\
\hline $\begin{array}{l}\text { Chow Test: Coefficient is } \\
\text { same as in Col. (1); resp. } \\
\text { Col. (3); resp. Col. (5) }\end{array}$ & . & {$[0.045]$} & & {$[0.040]$} & . & {$[0.027]$} \\
\hline Country Fe & Yes & Yes & Yes & Yes & Yes & Yes \\
\hline Year Fe & Yes & Yes & Yes & Yes & Yes & Yes \\
\hline Observations & 2314 & 2269 & 2459 & 2124 & 2267 & 2316 \\
\hline
\end{tabular}

Note: The dependent variable is the log-change of real per capita GDP. The method of estimation is least squares; t-values (shown in parentheses) below the point estimates are based on Huber robust standard errors that are clustered at the country level. P-values are reported [in square brackets] on the null hypothesis of the Chow test that the point estimate in column (1) (respectively, column (3) and (5)), on the ComPrice Shock, $t-1$ variable is the same as in column (2) (respectively, column (4) and (6)). Democracy (Autocracy) refers to countries that according to the Polity IV database have a strictly positive (negative) Polity2 score. Strong (weak) executive constraints refers to countries that have according to the Polity IV database an above (below) median sample score of executive constraints; strong (weak) political competition refers to countries that have according to the Polity IV database an above (below) median sample score of political competition. *Significantly different from zero at 90 percent confidence, $* * 95$ percent confidence, $* * * 99$ percent confidence. 


\section{Table 7. Commodity Price Shocks, Political Institutions, and the Risk of Default on External Debt}

\section{Default on External Debt}

\begin{tabular}{|c|c|c|c|c|c|c|}
\hline & Democracy & Autocracy & $\begin{array}{l}\text { Strong Executive } \\
\text { Constraints }\end{array}$ & $\begin{array}{c}\text { Weak Executive } \\
\text { Constraints }\end{array}$ & $\begin{array}{l}\text { Strong Political } \\
\text { Competition }\end{array}$ & $\begin{array}{c}\text { Weak Political } \\
\text { Competition }\end{array}$ \\
\hline & (1) & (2) & (3) & (4) & (5) & (6) \\
\hline & Logit FE & Logit FE & Logit FE & Logit FE & Logit FE & Logit FE \\
\hline ComPrice Shock, t-1 & $\begin{array}{l}-12.925 \\
(-1.00)\end{array}$ & $\begin{array}{l}9.759^{*} \\
(1.81)\end{array}$ & $\begin{array}{c}-15.984 \\
(-1.36)\end{array}$ & $\begin{array}{c}16.009^{* * *} \\
(2.69)\end{array}$ & $\begin{array}{c}-14.278 \\
(-1.17)\end{array}$ & $\begin{array}{c}10.525^{* *} \\
(1.97)\end{array}$ \\
\hline $\begin{array}{l}\text { Chow Test: Coefficient is } \\
\text { same as in Col. (1); resp. } \\
\text { Col. (3); resp. Col. (5) }\end{array}$ & . & [0.059] & . & {$[0.007]$} & . & [0.016] \\
\hline Country Fe & Yes & Yes & Yes & Yes & Yes & Yes \\
\hline Year Fe & Yes & Yes & Yes & Yes & Yes & Yes \\
\hline Observations & 640 & 1174 & 708 & 1106 & 638 & 1176 \\
\hline
\end{tabular}

Note: The dependent variable is an indicator variable that is 1 if the country defaulted on external debt. The method of estimation for the conditional logit fixed effects model is maximum likelihood. P-values are reported [in square brackets] on the null hypothesis of the Chow test that the point estimate in column (1) (respectively, column (3) and (5)) on the ComPrice Shock, $t-1$ variable is the same as in column (2) (respectively, column (4) and (6)). Democracy (Autocracy) refers to countries that according to the Polity IV database have a strictly positive (negative) Polity2 score. Strong (weak) executive constraints refers to countries that have according to the Polity IV database an above (below) median sample score of executive constraints; strong (weak) political competition refers to countries that have according to the Polity IV database an above (below) median sample score of political competition. *Significantly different from zero at 90 percent confidence, $* * 95$ percent confidence, $* * * 99$ percent confidence. 